\title{
Cross Sectional Analysis of Short Sale Determinants on U.S. Blue Chips
}

\author{
Dagmar Linnertová \\ Masaryk University \\ Faculty of Economics and Administration, Department of Finance \\ Lipová 41, 60200 Brno, Czech Republic \\ E-mail: Dagmar.Linnertova@mail.muni.cz
}

\begin{abstract}
Short sale is a market practice that allows participle in overpricing markets. The fundamental goal of short sale is to sell borrowed securities, repurchase them back after their prices decrease and then return them to a lender. The aim of this paper is to investigate determinants of the short sale (measured by short sale ratio or SIR) activity. Based on the previous studies the short sale determinants are represented by market specific variables and fundamental-to-price ratios and correspond with hypotheses that explain investor motivations of going short. A panel regression with fixed effect is applied to determine these variables. The trend of short sale is analyzed by splitting the full sample period in three sub periods. There are identified factors such as abnormal rate of return, volume of trade, volatility, market capitalization and beta coefficient that are stable long term and influence the level of short sale. The results of fundamentals-to price ratio is not unambiguous and these variables do not considerably influence the level of short sale.
\end{abstract}

Keywords: short sale, determinants, panel regression, S\&P 500, hypotheses of going short

JEL codes: G10, G14

\section{Introduction}

The short sale is a market mechanism that allows the potential to capitalize overpricing of securities or to participate in a decreasing market. A short sale is a sale of a stock that a subject does not own in the time of a transaction, but has borrowed it from a lender that may be represented by a large institutional investor, brokerage house or a broker-dealer. A short seller opens his position by selling borrowed securities and closes his position by purchasing securities back and returning them to a lender. The whole transaction is backed by collateral. The mechanism of short selling is demonstrated in Figure 1. The first part of Figure 1 represents the process of shorting, while the second part notes the closing of a position. 
Figure 1 Short Sale Mechanism

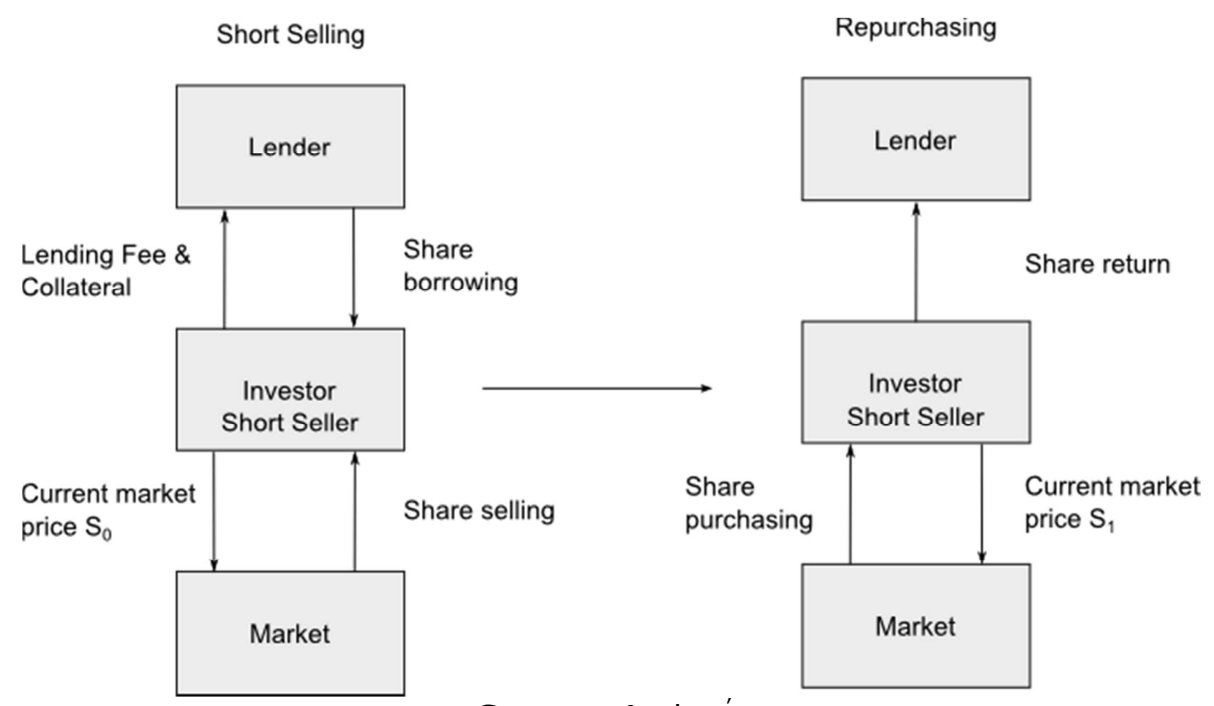

Source: Author's

The profit-loss profile of a short seller is described in Figure 2. The maximum gain of the short seller is the sale price $\left(S_{0}\right)$ of the stock at the time $t=0$ if the stock price falls at zero at the time $t=1$. The loss is unlimited if the stock price rises. The transaction costs are not taken into account in this scheme. The standard stock-lending practice is that the loan must be repaid on the demand. The specific risk calling a short squeeze emerges because of this practice. While term basis loans exist, they are more expensive and rare.

Figure 2 Profit and Loss Profile of a Short Seller

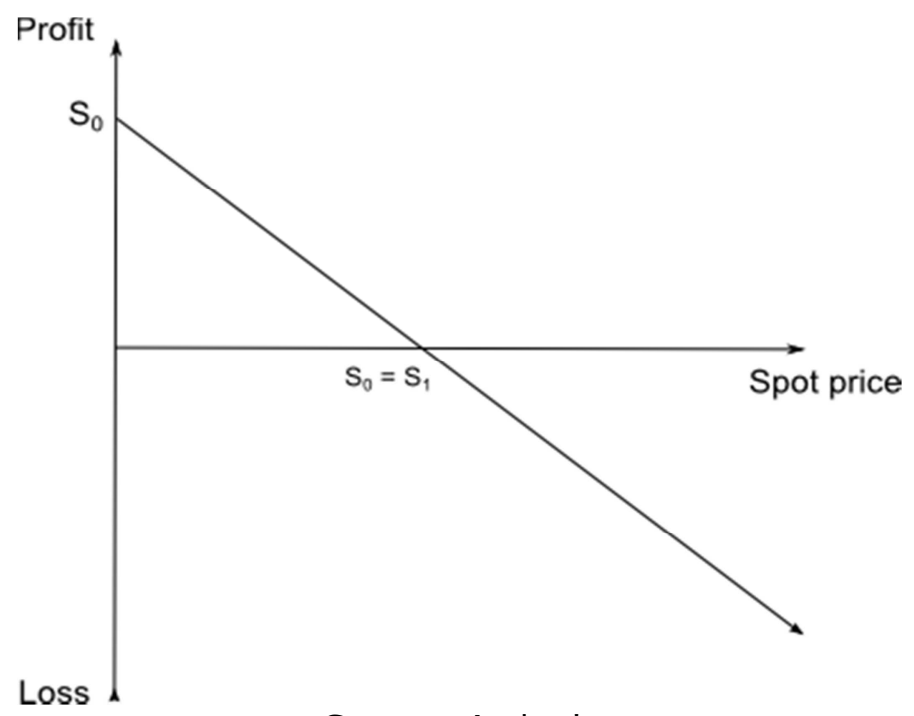

Source: Author's 
Because of the high risk associated with short selling it is also an activity that is heavily regulated. In the U.S. short sale was made more difficult because of the adoption of so called tge uptick rule that went into effect in 1938 and was removed in 2007. In 2009, the reintroduction of the uptick rule was widely debated, and proposals for a form of its reintroduction by the SEC. A modified form of the rule was adopted in 2010.

\section{Related Literature on Short Interest}

The motivations of the investor for short selling are summarized in four hypotheses. Trend Hypothesis (1) (also known as Following the Trend Hypothesis) states that short sellers close their positions if the stock prices have been increasing in the past short term. Jagadeesh \& Titman (1993) demonstrate that the stocks with high (low) rate of returns at the horizon from 3 to 12 months are repeating this high (low) rate of return at the horizon of next 3 to 12 months. The overpricing hypothesis (2) expects that investors have inside information and if they expect that the stock is overpriced the short selling is a way to capitalize it. Diamond and Verreichia (1987) point out that short sale is an expensive transaction and short sellers trade only if they expect that the price will significantly decrease as compensation for this cost and risk. Dechow et al. (2001) emphasize the relationship between the low fundamental factors and the level of short selling. The arbitrage hypothesis (3) argues that short sellers participate in overpricing between a stock and convertible security. High correlation between an instrument and instrument that is going short is demanded. And the taxation hypothesis (4) has only limited impact on short interest nowadays because of elimination of the opportunity to defer capital gain tax by shorting the investor's securities. (Arnold et al., 2005)

The aim of this paper is to analyze short sale determinants in the period 20002014 and particular sub periods. Based on previous literature reviews the determinants of short sale are represented by two categories - market specific and fundamentals-to-price. The analyzed periods reflect different economical and financial conditions. The period 2000-2006 is the term of economic growth that came out with the bankrupcy of Lehman Brothers. The first years of the 2000s were weak because of uncertainty following the September 2001 crisis and fraud cases of corporation but the economy of the U.S. improved during 2003 and was generally stable till the end of this sub period. The interval 2007-2009 represents financial market uncertainty, a real estate bubble and the epoch of a sub-prime crisis that passed into to world financial crisis. The last period 20102014 represents the first years of the world economy recovery. 
Brent et al. (1990) analyzed the motivation for short selling based on the three above-mentioned hypotheses. They found that short interest follows a seasonal pattern that is weakly consistent with the tax hypothesis. Further stocks with high betas and the existence of convertible securities or options tend to have a higher level of short interest. This supports the arbitrage motivation for short sale. The list of analyzed determinants is summarized in Table 1.

Table 1 Short Selling Determinants Analyzed by Brent et al.

\begin{tabular}{|c|c|c|}
\hline Analyzed determinant & $\begin{array}{c}\text { Expected impact } \\
\text { on short sale interest }\end{array}$ & $\begin{array}{c}\text { Motivation / } \\
\text { Hypothesis }\end{array}$ \\
\hline $\begin{array}{l}\text { Average market value of } \\
\text { shares during year proxy } \\
\text { for firm size }\end{array}$ & Unknown & Transactions costs \\
\hline $\begin{array}{c}\text { Average coefficient of } \\
\text { variation of analyst } \\
\text { forecast of the next } \\
\text { annual earnings during } \\
\text { year }\end{array}$ & Unknown & Speculation \\
\hline Systematic risk (beta) & Positive & $\begin{array}{c}\text { Arbitrage and hedging } \\
\text { hypothesis }\end{array}$ \\
\hline $\begin{array}{l}\text { Prior year's average } \\
\text { monthly return }\end{array}$ & Unknown & Speculation \\
\hline $\begin{array}{c}\text { Dummy for convertible } \\
\text { security existence }\end{array}$ & Positive & $\begin{array}{c}\text { Arbitrage and hedging } \\
\text { hypothesis }\end{array}$ \\
\hline $\begin{array}{l}\text { Dummy for option } \\
\text { existence }\end{array}$ & $\begin{array}{l}\text { Positive if arbitrage } \\
\text { reasons or negative if } \\
\text { substitute to short sale }\end{array}$ & Arbitrage or Speculation \\
\hline
\end{tabular}

Source: Author's summary of Brent et al. (1990)

Dechow et al. (2001) document that short sellers open positions in stock of firms with low ratios of fundamentals (like earnings or book value) to market value and close their positions at the ratios mean-revert. They also point out the importance of transactions costs in the decision making process of short sellers. Angel et al. (2003) examine the frequency of short selling in stocks listed in NASDAQ and analyzed stock characteristics. They get that short sale is more common among stocks with high returns than stocks with weaker performance and further actively traded stocks are more shorted. Short selling also depends directly and positively on stock price volatility. Desai et al. (2002) examines the relationship between the level of short interest and stock return on the NASDAQ. They find out that heavily shorted stocks experience significant negative abnormal returns with respect to the market, size, book-to-market and momentum factors. The higher level of short interest is a stronger bearish signal. Kot (2007) finds that 
short-selling activity is positively related to arbitrage opportunities and hedging demand, and negatively related to previous short-term returns.

Based on previous studies the characteristics affecting the level of short sale measured by short interest ratio in the period 2000-2014 are summarized in Table 2.

Table 2 Variable Characteristics

\begin{tabular}{|c|c|c|c|c|}
\hline Variable & Abbrev. & Definition & $\begin{array}{c}\text { Expected } \\
\text { effect }\end{array}$ & Motivation \\
\hline $\begin{array}{l}\text { Short interest } \\
\quad \text { ratio }\end{array}$ & SIR & $\begin{array}{l}\text { Average number of } \\
\text { days for closing all } \\
\text { open short sale } \\
\text { positions }\end{array}$ & - & - \\
\hline $\begin{array}{c}\text { Market } \\
\text { Capitalization } \\
\text { (logarithm) }\end{array}$ & LOGCAP & $\begin{array}{l}\text { Proxy for company } \\
\text { size. Dollar market } \\
\text { value of all shares } \\
\text { outstanding. }\end{array}$ & $\begin{array}{l}\text { Positive/ } \\
\text { Negative }\end{array}$ & $\begin{array}{c}\text { Transactions } \\
\text { costs/ } \\
\text { Overpricing } \\
\text { hypothesis }\end{array}$ \\
\hline $\begin{array}{l}\text { Volume of } \\
\text { trade } \\
\text { (logarithm) }\end{array}$ & LOGVOLUME & $\begin{array}{c}\text { The total quantity of } \\
\text { shares bought and } \\
\text { sold during a } \\
\text { particular period. }\end{array}$ & $\begin{array}{l}\text { Positive/ } \\
\text { Negative }\end{array}$ & $\begin{array}{c}\text { Transactions } \\
\text { costs/ } \\
\text { Overpricing } \\
\text { hypothesis } \\
\end{array}$ \\
\hline Volatility & VOL & $\begin{array}{l}\text { A measure of the risk } \\
\text { of price moves for } \\
\text { security calculated } \\
\text { from the standard } \\
\text { deviation }\end{array}$ & Positive & $\begin{array}{l}\text { Overpricing } \\
\text { hypothesis }\end{array}$ \\
\hline $\begin{array}{c}\text { Beta } \\
\text { coefficient }\end{array}$ & BETA & The systematic risk & Positive & $\begin{array}{c}\text { Arbitrage and } \\
\text { Hedging } \\
\text { Hypothesis } \\
\end{array}$ \\
\hline $\begin{array}{l}\text { Price-to-Book- } \\
\text { Value }\end{array}$ & PBV & $\begin{array}{c}\text { A ratio used to } \\
\text { compare a stock's } \\
\text { market value to its } \\
\text { book value. } \\
\text { Low value might } \\
\text { indicate } \\
\text { undervaluation } \\
\text { of a stock. }\end{array}$ & Negative & $\begin{array}{l}\text { Overpricing } \\
\text { hypothesis }\end{array}$ \\
\hline $\begin{array}{l}\text { Price-to- } \\
\text { Earnings }\end{array}$ & PE & $\begin{array}{c}\text { A valuation ratio of a } \\
\text { company's current } \\
\text { share price compared } \\
\text { to its per-share } \\
\text { earnings. }\end{array}$ & Negative & $\begin{array}{l}\text { Overpricing } \\
\text { hypothesis }\end{array}$ \\
\hline Price-to-Sales & PS & $\begin{array}{l}\text { A valuation ratio that } \\
\text { compares a } \\
\text { company's stock price } \\
\text { to its revenues. }\end{array}$ & Negative & $\begin{array}{l}\text { Overpricing } \\
\text { hypothesis }\end{array}$ \\
\hline
\end{tabular}




\begin{tabular}{|c|c|c|c|c|}
\hline Variable & Abbrev. & Definition & $\begin{array}{l}\text { Expected } \\
\text { effect }\end{array}$ & Motivation \\
\hline $\begin{array}{c}\text { Price-to-Free- } \\
\text { Cash-Flow }\end{array}$ & PFCF & $\begin{array}{l}\text { A valuation metric } \\
\text { that compares a } \\
\text { company's market } \\
\text { price to its level of } \\
\text { annual free cash flow. }\end{array}$ & Negative & $\begin{array}{l}\text { Overpricing } \\
\text { hypothesis }\end{array}$ \\
\hline $\begin{array}{l}\text { Abnormal rate } \\
\text { of return }\end{array}$ & $A B$ & $\begin{array}{c}\text { A measure of the } \\
\text { difference between } \\
\text { the return on the } \\
\text { stock and the risk free } \\
\text { security represented } \\
\text { by T-Bonds }\end{array}$ & Negative & $\begin{array}{l}\text { Overpricing } \\
\text { hypothesis }\end{array}$ \\
\hline Dividend yield & YIELD & $\begin{array}{l}\text { A financial ratio that } \\
\text { shows how much a } \\
\text { company pays out in } \\
\text { dividends each year } \\
\text { relative to its share } \\
\text { price }\end{array}$ & Negative & $\begin{array}{l}\text { Overpricing } \\
\text { hypothesis }\end{array}$ \\
\hline
\end{tabular}

Source: Author's

Short interest ratio is defined as the short interest (number of stocks shorted) divided by the average daily trading volume. It represents the dependant variable in the panel.

Volume of trade indicates that short sellers prefer stocks with larger trading volumes that are more liquid. Volume of trade is measured as a monthly traded average number of securities. The expected impact of the volume of trade on short interest ratio is positive and it is based on problems with transactions costs. On the other hand advocates of overpricing hypothesis expected negative impact because less liquid stocks are more likely overpriced.

Market capitalization is included in the analyses because smaller firms are associated with more overreaction and smaller market capitalization firms may be more sensitive to mispricing because they have a smaller investor following Cox \& Peterson (1994). If transactions costs are taken into account firms with large market capitalization are cheaper for short selling because their liquidity. Thus the effect of market capitalization on short interest may be positive.

Abnormal return as one analyzed determinant corresponds with the findings of Angel et al. (2003) that short sellers choose a stock of firms that have experienced significant price run-ups. This is due to the fact that the investor expects a potential correction in response to the market's previous overreaction. 
Beta coefficient measures the systematic risk, McDonald and Baron (1973) suggest that short interest is positively correlated with beta. That is an assumption of a successful arbitrage or hedging activity.

Volatility as a short sale determinant corresponding with the overpricing hypothesis and suggests that more volatile stocks may be a subject of mispricing, Richards (1997). This also matches the findings of Angel et al. (2003) about targeting more volatile stocks for short selling.

Dividends make short sale more expensive because all dividend payments must be redistributed to a lender. Thus, short sellers may avoid stocks with higher dividend yield.

The fundamentals-to-price ratios are represented by Price-To-Earnings, Priceto-Book Value, Price-to-Free Cash Flow and Price-to Sales. According to Dechow (2001) statistically significant concentration of short positions in firms with low fundamentals-to-price ratios exists, but not all stocks with low fundamentals-toprice ratios are heavily shorted. The reasons are transactions costs and existence of additional information that a stock is not overprices.

The trend in short sale activity is investigated splitting up the examined period into three sub periods.

\section{Methodology and Data}

The cross-sectional panel regression is carried out for 502 stock representing Standard and Poor's 500 Index in the period 2000-2014. The data was gathered from the Bloomberg and the analysis is based on 73,752 monthly observations. The development of short selling activity measures by short interest ratio (statistical mean) is documented in the Figure 3. The full dataset is spit into three sub periods representing different economics conditions for the comparison of short sale determinants. Particular sub periods are following:

- Sub period 2000-2006 or pre crisis period

- Sub period 2007-2009 or crisis period

- Sub period 2010-2014 or post crisis period or period or the recovery

For the period 2000-2014 the highest level of SIR was 6 day and the lowest was 2.5 days on the average. In the sub period 2000-2006 the short sale reached its peak in 2004 with SIR 5.5 days at the same period the minimum SIR was represented by 3.5 day in 2001. In the crisis period (2007-2009) the SIR was more volatile and it reached minimum of 2.5 days in 2007. In the subsequent period SIR has been increasing toward a new maximum of 6 days in 2014 . 
Figure 3 Short Interest Ratio (SIR) in the period 2000-2014

\section{Mean of SIR}

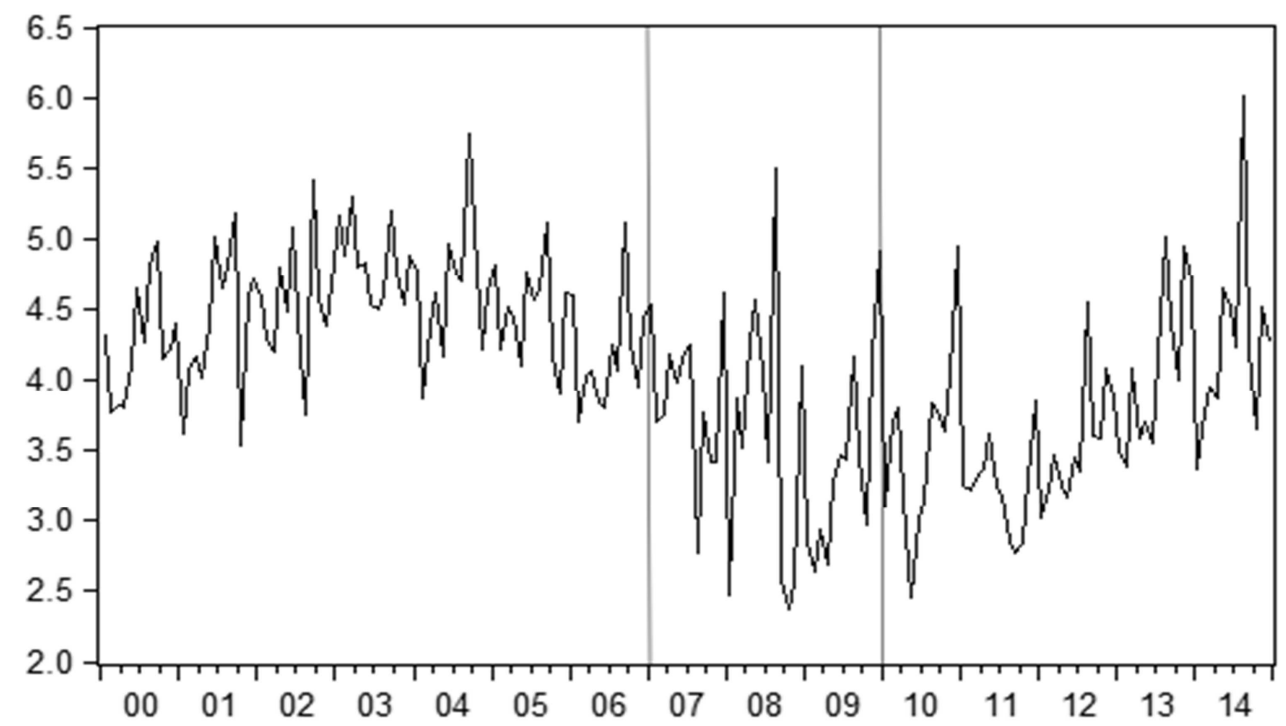

Source: Author in Eviews

The summary statistics for the whole sample and sub periods is set in the Table 4 and Figure 4, respectively. The average SIR for analyzed period is 3.91 days. The level of short sale was above average in the period 2000-2006 and lower in the crisis and after the crisis period. But in the after crisis period some form of a recovery could be identified.

Table 4 Sample statistics

\begin{tabular}{lcccc}
\hline \multicolumn{1}{c}{ Variable } & $\begin{array}{c}\text { Full } \\
\text { sample }\end{array}$ & $\mathbf{2 0 0 0 - 2 0 0 6}$ & $\mathbf{2 0 0 7 - 2 0 0 9}$ & $\mathbf{2 0 1 0 - 2 0 1 4}$ \\
\hline Short interest ratio & 3.91 & 4.25 & 3.57 & 3.74 \\
& $(2.99)$ & $(3.36)$ & $(2.69)$ & $(2.79)$ \\
\hline Abnormal rate & -0.02 & -0.03 & -0.04 & -0.01 \\
of return & $(-0.02)$ & $(-0.03)$ & $(-0.03)$ & $(-0.01)$ \\
\hline \multirow{2}{*}{ Beta coefficient } & 1.05 & 0.98 & 1.09 & 1.12 \\
& $(0.98)$ & $(0.86)$ & $(1.01)$ & $(1.04)$ \\
\hline Market capitalization & 9.34 & 9.05 & 9.32 & 9.65 \\
(logarithm) & $(9.25)$ & $(8.99)$ & $(9.19)$ & $(9.50)$ \\
\hline Volume of trade & 16.98 & 17.23 & 17.18 & 16.61 \\
(logarithm) & $(16.92)$ & $(17.19)$ & $(17.13)$ & $(16.57)$ \\
\hline \multirow{2}{*}{ Price-to-Book Value } & 8.09 & 6.25 & 5.11 & 11.69 \\
& $(2.69)$ & $(2.91)$ & $(2.44)$ & $(2.59)$ \\
\hline \multirow{2}{*}{ Price-to-Earnings } & 31.89 & 31.26 & 32.75 & 32.10 \\
& $(17.97)$ & $(19.65)$ & $(16.23)$ & $(17.25)$ \\
\hline
\end{tabular}




\begin{tabular}{lcccc}
\hline \multicolumn{1}{c}{ Variable } & $\begin{array}{c}\text { Full } \\
\text { sample }\end{array}$ & 2000-2006 & 2007-2009 & \multirow{2}{*}{$\mathbf{2 0 1 0 - 2 0 1 4}$} \\
\hline Price-to-Sales & 2.42 & 2.61 & 2.11 & 2.39 \\
& $(1.61)$ & $(1.57)$ & $(1.38)$ & $(1.74)$ \\
\hline Price-to-Free Cash & 95.19 & 137.89 & 66.90 & 137.89 \\
Flow & $(19.12)$ & $(21.07)$ & $(18.06)$ & $(21.07)$ \\
\hline \multirow{2}{*}{ Dividend yield } & 1.90 & 1.63 & 2.43 & 1.63 \\
& $(1.26)$ & $(1.05)$ & $(1.36)$ & $(1.05)$ \\
\hline
\end{tabular}

The numbers in the brackets are the medians.

Source: Author in Eviews

Figure 4 Volatility, Abnormal Rate of Return, Volume of Trade and SIR in the period 2000-2014

VOLATILITY

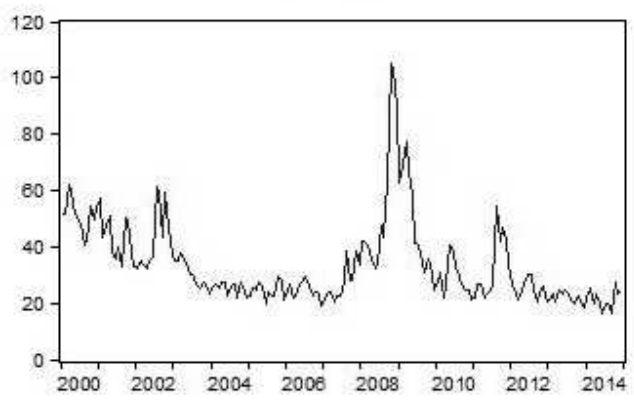

LOGVOLUME

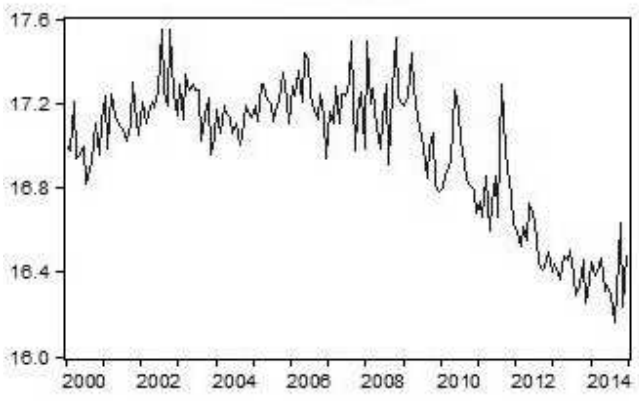

SHORT INTEREST RATIO

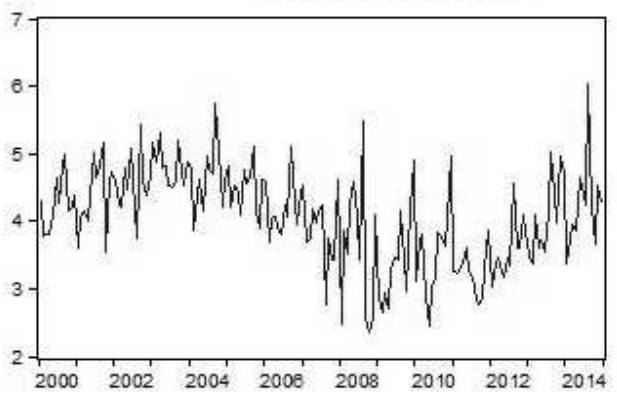

ABNORMAL RATE OF RETURN

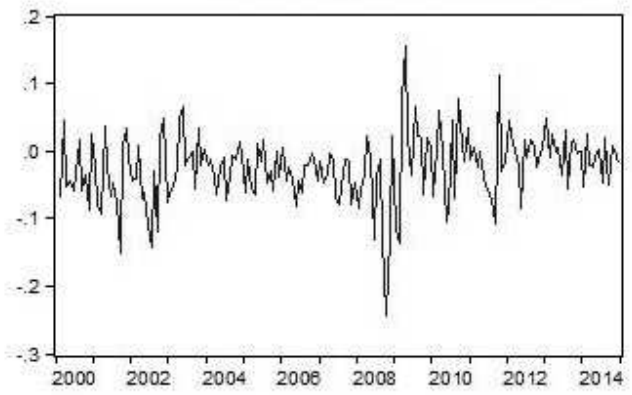

\section{-Mean}

Source: Author's in Eviews

In the paper the cross-sectional panel regression is applied. Consider the multiple linear regression model for individual $\mathrm{i}=1, \ldots, N$ that is observed at several time period $t=1, \ldots, T$. 


$$
y_{i t}=\alpha_{i}+x^{\prime}{ }_{i t} \beta+z^{\prime}{ }_{i} \gamma+c_{i}+u_{i t}
$$

Where $y_{i t}$ is the dependent variable, $x^{\prime}{ }_{i t}$ is a $K$ - dimensional row vector of timevarying explanatory variables and $z_{i}^{\prime} \gamma$ is a $M$-dimensional row vector of timeinvariant explanatory variables excluding the constant, $\alpha$ is the intercept, $\beta$ is a $K$ dimensional column vector of parameters, $\gamma$ is a $M$-dimensional columns of vector of parameters, $c_{i}$ is a individual-specific effect and $u_{i t}$ is an idiosyncratic error term. We assume the balanced panel that each individual $i$ is observed in all time periods $t$. There are two basic models for the analysis of panel data, the fixed effect model and the random effect model. For the fixed effects model, the individual-specific effect is a random variable that is allowed to be correlated with the explanatory variables, in the random effects model is random variable uncorrelated with explanatory variables.

In a fixed effects model an individual-specific intercept is included in the model (1). In this case, the model is written as

$$
y_{i t}=\alpha_{i}+x^{\prime}{ }_{i t} \beta+u_{i t}, \quad u_{i t} \sim \operatorname{IDD}\left(0, \sigma_{u}^{2}\right)
$$

Where $\alpha_{i}(i=1, \ldots, N)$ are fixed unknown constants that are estimated along with $\beta$, and where $u_{i t}$ is typically assumed to be i.i.d. over individuals and time. To decide between fixed or random effect the Hausman test was run where null hypothesis is that the preferred model is random vs. alternative the fixed effects. The Hausman test statistic is computed as

$$
\xi_{H}=\left(\hat{\beta}_{F E}-\hat{\beta}_{R E}\right)^{\prime}\left[\hat{V}\left\{\hat{\beta}_{F E}\right\}-\widehat{V}\left\{\hat{\beta}_{R E}\right\}\right]^{-1}\left(\hat{\beta}_{F E}-\hat{\beta}_{R E}\right)
$$

Where the $\widehat{V S}$ denote estimates of the true covariance matrices. Under the null hypothesis, which implicitly says that $\operatorname{plim}\left(\hat{\beta}_{F E}-\hat{\beta}_{R E}\right)=0$, the statistic $\xi_{H}$ has an asymptotic Chi-squared distribution with $K$ degrees of freedom, where $\mathrm{K}$ is the number of elements in $\beta$. Based on Hausman test result the fixed effect model was chosen for further analysis. As a dependent variable in fixed effect model is chosen short interest ratio and the explanatory variables are represented by a market specific and fundamentals to price variables.

In the Table 5 are set correlation coefficients between variables. The correlation coefficients are weak thus the effect of multicolinearity might be neglected. 
Table 5 Correlation matrix

\begin{tabular}{c|ccccccccccc} 
& SIR & AB & VOL & BETA & LOGKAP & LOGVOL & PBV & PE & PS & PFCF & YIELD \\
\hline SIR & $\mathbf{1}$ & 0.03 & -0.12 & -0.05 & -0.27 & -0.3 & 0 & 0.02 & -0.01 & 0.01 & 0.02 \\
AB & 0.03 & $\mathbf{1}$ & -0.06 & 0.04 & 0.01 & -0.06 & 0.01 & 0.02 & 0.04 & 0 & -0.04 \\
VOL & -0.12 & -0.06 & $\mathbf{1}$ & 0.23 & -0.24 & 0.25 & 0 & 0.04 & 0.06 & 0.01 & 0.15 \\
BETA & -0.05 & 0.04 & 0.23 & $\mathbf{1}$ & -0.04 & 0.13 & 0 & 0.04 & 0.06 & -0.01 & -0.04 \\
LOGKAP & -0.27 & 0.01 & -0.24 & -0.04 & $\mathbf{1}$ & 0.48 & 0.02 & -0.01 & 0.11 & -0.01 & -0.01 \\
LOGVOLUME & -0.3 & -0.06 & 0.25 & 0.13 & 0.48 & $\mathbf{1}$ & -0.01 & 0.03 & 0.08 & 0 & -0.01 \\
PBV & 0 & 0.01 & 0 & 0 & 0.02 & -0.01 & $\mathbf{1}$ & 0 & 0.02 & 0 & 0 \\
PE & 0.02 & 0.02 & 0.04 & 0.04 & -0.01 & 0.03 & 0 & $\mathbf{1}$ & 0.2 & 0.02 & -0.02 \\
PS & -0.01 & 0.04 & 0.06 & 0.06 & 0.11 & 0.08 & 0.02 & 0.2 & $\mathbf{1}$ & 0.02 & -0.06 \\
PFCF & 0.01 & 0 & 0.01 & -0.01 & -0.01 & 0 & 0 & 0.02 & 0.02 & $\mathbf{1}$ & 0 \\
YIELD & 0.02 & -0.04 & 0.15 & -0.04 & -0.01 & -0.01 & 0 & -0.02 & -0.06 & 0 & $\mathbf{1}$
\end{tabular}

Source: Author in Eviews

\section{Results}

Table 6 and Table 7 provide the results of the fixed effect panel regression model for the full period and for particular sub periods. The statistical significance of determinants is stable long-term and also the impact of the determinants in the level of short interest measures with short interest period is constant.

Table 6 Panel Regression Results - Full Sample

\begin{tabular}{lc}
\hline Variable & Full Period \\
\hline Constant & 23.4620 \\
Abnormal rate of return & $0.3361^{* * *}$ \\
Volatility & $-0.0181^{* * *}$ \\
Beta coefficient & $0.0834 * * *$ \\
Market Capitalization (logarithm) & $-0.8108 * * *$ \\
Volume of trade (logarithm) & $-0.6800 * * *$ \\
Price-to-Book-Value & 0.0000 \\
Price-to-Earnings & $0.0001 * *$ \\
Price-to-Sales & $0.0301 * * *$ \\
Price-to-Free-Cash-Flow & 0.0000 \\
Dividend yield & 0.0015 \\
\hline R & 0.3617 \\
Number of observations & 73,752 \\
\hline
\end{tabular}

$*$, $* *$ and $* * *$ indicate significance at the $10 \%, 5 \%$ and $1 \%$ level, respectively

Source: Author in Eviews 
For the full period the factor that positively affected the short interest ratio are represented by an abnormal rate of return, beta coefficient, Price-to-Earnings ratio and Price-to-Sales. A negative effect was recorded for volatility, market capitalization and volume of trade. The strongest positive factor influencing short interest level is an abnormal rate of return (0.336) and the strongest negative factors are market capitalization $(-0.811)$ and volume of trade $(-0.680)$. The power of other significant factors is considerably weaker. Statistical significance of abnormal return, volume of trade and market capitalization support the overpricing hypothesis. The negative impact of volatility on short sale level indicates that investors do not open short position if they cannot anticipate the future market movement and limited short sale activities with risky stocks. A positive value of beta coefficient supports the idea about the arbitrage or hedging. Only two fundamentals-to-price characteristics are statistically significant but the effect of them on short sale level is against expectation. The power of these variables to the total short interest ratio is weak. The coefficient of determination is 36.2 percent.

Table 7 Panel Regression Results - Sub Samples

\begin{tabular}{lccc}
\hline Variable & $\mathbf{2 0 0 0 - 2 0 0 6}$ & $\mathbf{2 0 0 7 - 2 0 0 9}$ & $\mathbf{2 0 1 0 - 2 0 1 4}$ \\
\hline Constant & 24.8953 & 28.0434 & 44.3426 \\
Abnormal rate of return & -0.0134 & $0.7452 * * *$ & $0.8643 * * *$ \\
Volatility & $-0.0170 * * *$ & $-0.0132 * * *$ & $-0.0216 * * *$ \\
Beta coefficient & $0.1800 * * *$ & $0.0767 * *$ & $0.1440 * * *$ \\
Market Capitalization (logarithm) & $-0.5071 * * *$ & $-0.3854 * * *$ & $-1.2985 * * *$ \\
Volume of trade (logarithm) & $-0.9002 * * *$ & $-1.1901 * * *$ & $-1.6764 * * *$ \\
Price-to-Book-Value & -0.0003 & $0.0010 *$ & 0.0000 \\
Price-to-Earnings & $0.0004 * *$ & 0.0000 & 0.0001 \\
Price-to-Sales & $0.0135 * *$ & $0.0440 * *$ & $0.0597 * * *$ \\
Price-to-Free-Cash-Flow & 0.0000 & $-0.0001 *$ & 0.0000 \\
Dividend yield & $-0.1269 * * *$ & 0.0019 & $0.0155 * * *$ \\
\hline $\mathrm{R}^{2}$ & 0.4527 & 0.5721 & 0.5879 \\
Number of observations & 29,987 & 15,557 & 28,209 \\
\hline
\end{tabular}

$*, * *$ and $* * *$ indicate significance at the $10 \%, 5 \%$ and $1 \%$ level, respectively

Source: Author in Eviews

In the pre-crisis period the abnormal rate of return misses statistical significance and dividend yield becomes negative and significant. The other variables remain unchanged. The strongest positive factor is a beta coefficient $(0.180)$ and volume of trade $(-0.900)$ and market capitalization $(-0.507)$ remain the strongest negative factors. The coefficient of determination is 45.3 percent. In the crisis 
period the abnormal returns becomes again statistically significant and positive. Compare with the previous period Price-to-Book-Value and Price-to-Free-CashFlow are other fundaments that get statistical significance. On the other hand only the variable Price-to-Sales has considerable interest. The beta coefficient during this period falls notably, compared to the previous beta coefficient notably indicating a decline in influence on the level of short sale. The abnormal rate of return becomes the strongest positive factor, while the strongest negative factor stays constant. The power of volume of trade increases and reaches the level of 1.190. Also in this sub period, the motivation for short sale is confirmed, summarized in the overpricing hypothesis and the arbitrage and hedging hypotheses, with also the transactions costs being considered. The coefficient of determination in this period is $\mathbf{5 7 . 2}$ percent. For the last period the $\mathrm{R}^{2}$ reaches the maximum of 58.8 percent. The list of market specific variables is still same like in all previous periods. The powerful positive factors are abnormal rate of return (0.864) and beta coefficient (0.144). The power of market capitalization and volume of trade increases and get new maximum of -1.299 and -1.676 , respectively. From the fundamentals variable, only Price-to-Sales is statistically significant.

Summarized results indicate that variables affecting short sale level are a longterm stable list of market specific variables. These variables are market specific and correspond with the overpricing hypothesis, the arbitrage and hedging hypothesis and support the influence of transactions costs on the level of short sale. The results of fundamental-to-price variables are mixed. Generally, the control of these variables to short sale level is weak.

\section{Conclusion}

The aim of the paper was to analyze short sale determinants in the period 20002014 on NYSE and in a particular sub period. The short sale was defined as a risky operation based on selling of borrowed security, aiming to gain from a market decrease. Since the data structure the fixed effect panel regression model was applied. The application of panel regression with fixed effect was also confirmed by the results of the Hausman test. Based on a previous literature review analyzed determinants were chosen with the respect to four hypotheses of investor motivations to the short sale. The monitor variables were dividend in two categories - company fundamentals-to-price ratios and market specific characteristics.

The results for the full sample confirmed the overpricing hypothesis and arbitrage and hedging hypothesis behind investors motivation for short sale. Based on findings transactions costs must be also taken into account. The strongest 
significant positive variables are abnormal are of return and beta coefficient. The strongest negative variables are represented by market capitalization and volume of trade. Thus investors prefer stock of small cap companies with lower volume of trade that noticed abnormal rate of return. More volatile securities are less popular for the short sale. The correlation between security and market is also important thus beta coefficient is positively related to the short sale level. These variables (with exception of abnormal rate of return in pre-crisis period) were confirmed as statistically significant during all analyzed sub periods. The results for fundamental-to-price ratios are unambitious. Thus, there exists a group of variables that is long term stable and has an effect on the level of short interest.

\section{References}

Angel, J. J et al. (2003). A close look at short selling on the Nasdaq Market. The Financial Analysis Journal, 59, pp. 66-74.

Arnold, T. et al. (2005). The information content of short interest: A natural experiment. The Journal of Business, 78(4), pp. 1307-1336.

Brent, A. et al. (1990). Short interest: Explanations and tests. The Journal of Financial and Quantitative Analysis, 25, pp. 273-289.

Cox, D. and Paterson, D. (1994). Stock returns Following Large one-day declines: Evidence on short-term reversals and longer-term performance. The Journal of Finance, 49, pp. 255-267.

Dechow, P. et al. (2001). Short-sellers, fundamental analysis, and stock return. The Journal of Financial Economics, 61, pp. 77-106.

Desai, H. et al. (2002). An investigation of the informational role of short interest in the Nasdaq market. The Journal of Finance, 57, pp. 2263-2287.

Diamond, D. W. and Verrecchia, R., E. (1987). Constraints on short-selling and asset price adjustment to private information. The Journal of Finance, 18, pp. 277-312.

Jagadeesh, N. and Titman, S. (1993). Returns to buying winners and selling losers: Implications for stock market efficiency. The Journal of Finance, 43, pp. 65-91.

Kot, H. W. (2007) What determines the Level of Short-Selling Activity? Financial Management [online]. Available at: WWW: http://staffweb.hkbu.edu.hk/hwkot/ finance/papers/03_ShortInterest_FM.pdf.

McDonald, J. and Baron, D. (1966). Risk and return on short positions in common stocks. The Journal of Finance, 28, pp. 97-107. 
Richards, A. J. (1997) Winner-loser reversals in national stock market indices: Can they be explained? The Journal of Finance. 52, pp. 2129-2144. 